\title{
Effectiveness of African catfish pituitary extracts, dagin and water flow for optimising egg production, fertilisation and hatchability in artificial spawning of Barbus altianalis
}

\author{
C. Aruho', M. T. Mwanja', F. Bugenyi ${ }^{2}$ and J. Rutaisire ${ }^{3}$ \\ ${ }^{1}$ National Fisheries Resources Research Institute, Aquaculture Research and Development \\ Center, P. O. Box 530, Kampala, Uganda \\ ${ }^{2}$ College of Natural Sciences, Department of Biological Science, Makerere University, \\ P. O. Box 7062, Kampala, Uganda \\ ${ }^{3}$ National Agriculture Research Organisation, P. O. Box 299, Entebbe, Uganda
}

Author for correspondence: aruhoc@gmail.com

\begin{abstract}
Fish inducing hormones are widely used in commercial aquaculture to facilitate continuous supply of sufficient seed required on regular basis by the farmers. The objective of this study was to optimise production of viable eggs for improved hatchability during artificial spawning in Barbus altianalis. Two experiments were conducted, namely (i) experiment I evaluated the efficiency of using catfish pituitary extracts in spawning of second generation broodstocks compared to that of Dagin and water flow. (ii) experiment II examined ripe running females facilitated to spawn by running water only. Fish treated with pituitary extracts performed much better than those treated by Dagin with respect to fertilisation rates at $80.27 \pm 39.57 \%$ $(\mathrm{U}=66.5, \mathrm{p}<0.001)$ and working fecundity at $2314.40 \pm 882.04(\mathrm{U}=59.5, \mathrm{p}<0.05)$. However, the difference in hatchability was not significant $(p>0.05)$. In experiment II, hatchability and working fecundity were significantly higher when fish were striped after 4 hours $(100$ degree hours at $25^{\circ} \mathrm{C}$ ) of running water than those striped after 10 hrs ( 250 degree hours) but fertilization rates were not different. The findings indicate that catfish pituitary extracts are more effective in inducing $B$. altianalis to spawn than those treated with Dagin. However, the observations made on ripe running females in both experiments suggest that they should not be induced with any hormone. Hence, the cost of spawning could further be reduced using running water, especially in wet seasons when the majority are ripe.
\end{abstract}

Key words: Eggs, hatchability, hormone, spawning 


\section{Introduction}

Manipulation of reproductive systems to induce oocyte maturation and ovulation in fish species using inducing hormones has widely been adopted in commercial aquaculture to facilitate continuous supply of sufficient seed required on regular basis by fish farmers (Bromage, 1998; Zohar and Mylonas, 2001). The regular availability of this seed is essential for closing the life cycle of fish in captivity (Funge-Smith and Phillips, 2001; Stickney, 2005). Fish species have an inherent mechanism that relates to the gonadal structure and activity with appropriate environmental stimuli that triggers spawning (Munro, 1990; Rutaisire et al., 2015). Under appropriate environmental stimuli relayed to the brain through the neuron system, sustained levels of releasing hormone $(\mathrm{GnRH})$ from the hypothalamus, triggers the release of luteinising hormone (LH) and follicle stimulating hormones (FSH), that control oocyte maturation and ovulation (Peter and Yu, 1997; Levavi-Sivan et al., 2010). Under culture conditions, the extent to which the inducing hormone effectively initiates oocyte maturation and ovulation depends on the levels of the GnRH hormone released by the brain in response to the stimuli. The nature and the source of the inducing agents influence and permit timely maturation and ovulation of viable eggs for incubation in a given species. The response to the inducing agent is species specific and may vary in dosages (Marte, 1989).

Although induced spawning was successful in B. altianalis (Rutaisire et al., 2015), the high mortality of eggs and yolk sac larval stage observed (about 55 and $11 \%$, respectively) could have been partly associated with the levels and timing of inducing hormone required to achieve optimal egg ripeness or quality. Both synthetic GnRH analogs and pituitary extracts (PE) have been used for induced spawning in the Chinese and Indian carps; but with analogs, higher success was registered when they are administered with anti-dopamine agents (Afzal, 2008; Levavi-Sivan et al., 2010). However, at over US\$ 100 for each vial used for only $10 \mathrm{~kg}$, synthetic analogues are expensive, hence are not readily available to fish farmers in East Africa. The pituitary extracts become an alternative cheaper source and readily available option to the farmers than the synthetic hormones. In the initial artificial spawning experiments, ovulation in wild $B$. altianalis broodstock was successfully facilitated by water flow (Rutaisire et al., 2015). The effectiveness of water to induce spawning could be linked to the maturation level of gravid individuals, whereby water flow facilitated increased hormonal release levels by encouraging courtship and excitement. However, still low egg production and hatchability was recorded (Rutaisire $e t$ al., 2015). Thus, the high embryonic mortality was probably linked to inadequate hormonal levels among other factors.

One of the most widely used natural hormones in inducing fish is the carp pituitary extract (CPE), which has been used with many different fish species (Rottman et al., 1991; Drori et al., 1994; Zohar and Mylonas, 2001; Yaron et al., 1984, 2009; Zohar et al., 2010). The pituitary extracts contain key two gonadotropins (GTHs), Luteinizing Hormone (LH) and Follicle Stimulating Hormone (FSH) that consist of identical weakly associated non-covalent dimer's of subunits joined to the more specialized units of amino acids (Weltzien et al., 2003). 
Increased levels of these hormones are associated with spawning activities in fish (Nagahama, 1994; Yaron et al., 2009). Although the effect of CPE is nonspecies specific across cultured carps (Chaudhuri, 1976), the response of the fish to CPE by increasing gonadotropin levels could vary in different species (Miah et al., 2008; Mahfuj et al., 2012). The CPE has registered success only with split dose administration (priming and resolving) in almost all the carps (Mahfuj et al., 2012; Indira et al., 2013). The CPE has never been used to induce spawning in $B$. altianalis. However, because of the scarcity of farmed carps in East Africa, alternative sources from other fish species like the African catfish Clarius gariepinus has been largely used to induce spawning in the same species (de Graaf and Janssen, 1996; Mwanja et al., 2015) and could be used as aheterologous gland for induced spawning in $B$. altianalis. The objective of this study was to evaluate the effect of African catfish pituitary extract on induced spawning and ovulation of $B$. altianalis compared to that of Dagin ([D-Arg6, Pro9-NEt])sGnRH; $10 \mu \mathrm{g} \mathrm{kg}^{-1}+$ metoclopramide 20 $\mathrm{mg} \mathrm{kg}^{-1}$ ), a GnRH synthetic analogue with an anti-dopamine drug (Drori et al., 1994), and use of running water alone with a view of determining its effectiveness in optimising egg production and larvae hatchability since it might be a cost effective option and readily available technique to farmers.

\section{Method and materials}

Preparation and feeding of broodstock A total of 79 fish of the first generation of parents from wild, ranging from 282 to 900 $\mathrm{g}$ were fed on commercial fish feed $(30 \%$
CP) for two months, in fertilised ponds of $300 \mathrm{M}^{2}$ (approx. one bag of $100 \mathrm{~kg}$ cow dung in $300 \mathrm{M}^{2}$ pond). The fish were fed 3 times daily, and the feed was applied at $5 \%$ body weight for the first one week and $3 \%$ body weight for the rest of the period (based on the farm's broodstock management protocol for catfish breeding). The broodstock feeding and spawning were done during the months of November and December 2015, at Ssenya Fish Farm, a commercial fish firm located in the Lwengo District (N0022194, E32.679772) in Uganda. In the first month, 48 females were fed separately from 31 males. However, about 15 females were found to have less than 300 eggs, and none of the males produced milt. They were then fed together in the second month before most of them became ripe for spawning.

\section{Preparation of catfish pituitary extract and dagin}

The catfish pituitary extract was prepared from the pituitary glands obtained from 31 catfish pieces of average $700 \pm 50 \mathrm{~g}$. Thirty one pituitary glands weighing on average $0.04 \mathrm{~g} \pm 0.008$, were crashed in a mortar and mixed with $3 \mathrm{ml}$ of $5 \%$ saline solution for each pituitary, as used by the same farm on catfish induction as well as some other farms (Mwanja et al., 2015). The solution contained a total of $1.33 \mathrm{~g}$ pituitary glands in $93 \mathrm{ml}$ of solution. Each $\mathrm{ml}$ contained $0.014 \mathrm{~g}$ pituitary extract and Dagin was administered according to the manufacturer's protocol for common carp $\left(10 \mu \mathrm{g} \mathrm{kg}^{-1}+20 \mathrm{mg} \mathrm{kg}^{-1}\right.$ sGnRHa- [DArg $^{6}$, Pro9-NEt]-sGnRH and metoclopramide, respectively). A standard prescribed dosage for carps, of $20 \mathrm{~kg}$ per $10 \mathrm{ml}$ in a vial was used in this experiment. 
Experiment I: Separation and treatment of Broodstocks with hormones

Forty five females were randomly separated into groups of 5 , and placed in $8 \mathrm{~m}^{3}$ (4 $\times 2 \times 1$ metres) concrete tanks making a total of 9 tanks. Three males were randomly placed in each of the nine tanks containing females and the fish were left to rest for $4 \mathrm{hrs}$ from $15-19.00 \mathrm{hr}$ (100 degree hours). Water flow was allowed through the tank at a rate of 1 litre per 20 second. The temperature was kept at 25 ${ }^{\circ} \mathrm{C}$. After $4 \mathrm{hrs}$, the fish in each tank was treated with catfish pituitary extract or Dagin. The fish in rest of the tanks were used as control and were not treated with any hormone. Each treatment had three replicates. Females that were treated with catfish pituitary extract were injected with the first dosage of $2 \mathrm{ml}$ of the pituitary extract for approximately $1 \mathrm{~kg}$ of $B$. altianalis broodstock $\left(0.028 \mathrm{~g} \mathrm{~kg}^{-1}\right)$. Those treated with Dagin, were injected with $0.5 \mathrm{ml}$ of Dagin hormone per $\mathrm{kg}$ of B. altianalis.

The cost of the two homones used is compared in Table 1. Hormones were administered intramuscularly. After 5 hrs (cumulative; 225 degree hours) between 19:30-00:30 hr, the fish were given the resolving dosage of $3 \mathrm{ml}$ for those treated with catfish pituitary extract , and $3 \mathrm{ml}$ for those treated with Dagin. At the time of the second injection, the males received 2 $\mathrm{ml}$ for those in the tanks treated with catfish pituitary extract and those that were treated with Dagin.

\section{Stripping and incubation of eggs}

After 6 hours of latency at $25 \pm 0.9{ }^{\circ} \mathrm{C}$, the fish was removed from the tanks and stripped. During stripping, about 5-10 eggs from each female were examined for development using acetic acid solution, to ascertain the position of nucleus (or to find 
out whether the eggs were ripe). The eggs from each fish were placed on $60 \mathrm{~cm} \mathrm{x}$ $30 \mathrm{~cm}$ trays made of $1 \mathrm{~mm}$ mesh size. The eggs were incubated at a temperature of $26.5 \pm 1^{\circ} \mathrm{C}$ in small concrete tanks of $100 \mathrm{~L}$. Dissolved oxygen was $6 \pm 1.2 \mathrm{mg}$ $\mathrm{L}^{-1}$ and $\mathrm{pH}$ range of 7-8. The eggs were incubated until hatching that started at $47.00 \mathrm{hr}$ (51.9 degree hours), and ended at $72.00 \mathrm{hr}$ (79.5 degree hours) in all the trays.

\section{Experiment II}

The second experiment was conducted 3 months later (April, 2016) using the same specimens. In this experiment, only females that had ripe running eggs (released by slightly pressing on the belly) were used. The females and males were housed and fed together for one month, following the procedure described in Experiment I above. After seining and identifying the ripe broodstock, 3 females were randomly placed in each of the 6 (4 $\mathrm{m} \times 2 \mathrm{~m} \times 1 \mathrm{~m}$ ) concrete tanks. Water was allowed to flow through at a rate of one 0.05 litres per second. Nine females from three tanks were stripped after $4 \mathrm{hrs}$, and the others were striped after $10 \mathrm{hrs}$ from the time they were distributed into the tanks. The water temperature was maintained at $25^{\circ} \mathrm{C}$. The eggs were incubated at $26.5 \pm 1{ }^{\circ} \mathrm{C}$ in small concrete tanks of $100 \mathrm{~L}$.

\section{Measuring parameters}

Fertilisation was determined after 30 minutes of incubation, by subsampling the eggs to identify early cleavage stage observed under the light microscope. Eggs without observable cleavage were considered unfertilised. Fertilization rate was calculated using the equation:

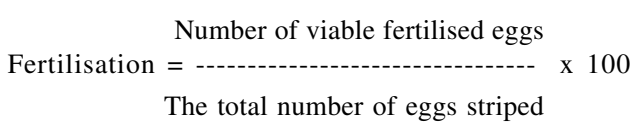

Working fecundity (number of striped eggs) was obtained by counting eggs for the fish that had fewer eggs; however, for fish with many eggs, a sample was taken and weighed and the number of eggs in the subsample was counted. An extrapolation of the sub sampled eggs was made with the number of eggs in a total weight to obtain the total number of eggs for each female.

Working fecundity $=$

Number of eggs (n) in a sample

Weight of the sample $\mathrm{w}$

x Total weight of eggs W

The hatchability was obtained by counting the number of hatched larvae of the total eggs incubated.

$$
\begin{gathered}
\text { Hatchability }= \\
\text { Number of hatched larvae } \\
\text {------ } \\
\text { Total number of eggs }
\end{gathered}
$$

\section{Data analysis}

Differences in the mean values among treatments were analysed using KruskalWallis in SPSS statistical software (IBM SPSS Statistics for Windows, Version 22.0. Armonk, NY: IBM Corp, 2013) at 95\% confidence level. Kruskal-Wallis was used because the mean values did not conform to the homogeneity rules of ANOVA. Significant differences between treatment means were determined by Mann-Whitney U test. Data were 
presented as means and their standard deviations (Mean $\pm \mathrm{SD}$ ).

\section{Results}

During broodstock feeding, males that were initially raised separately from the females did not exude milt on pressing the belly, but on bringing them together in the second month, all males except 3 were found with some milt (varying from 1-5 $\mathrm{ml}$ ). On the other hand, 26 females out of 48 produced some eggs either by pressing on the belly and or by use of a catheter. Twenty two males responded to the hormone by producing clear running milt, which was more than $5 \mathrm{ml}$. However, 5 males from the control group (with water current) had less than $2 \mathrm{ml}$ of the milt on slight pressure on the abdomen; hence, they were not considered to be suitable for fertilising the ripe females. When the catfish pituitary extract was administered, it was found that all the females ovulated or produced some eggs when stripped on the belly. However, two females, one from a replicate treated with Dagin and another from the replicate in a control tank, did not produce eggs when pressed at the belly.

Ovulation rate (all those that released eggs) for catfish treated pituitary extract was $100 \%$ (15 fish), $93.3 \%$ (14 fish) for Dagin treated fish and $93.3 \%$ (14 fish) for control water treatments (Table 2). However, not all those that produced eggs fertilised and or hatched. Fertilisation rates ranged from 0 to $100 \%$. Differences in fertilisation rates were observed among the hormonal treatments (Kruska-Wallis $\left.\chi^{2}=15.13, \mathrm{df}=2, \mathrm{p}<0.001\right)$. Mean fertilisation rate for females treated with catfish pituitary was $80.27 \pm 39.57 \%$, and was significantly higher than $40.8 \pm 50.05 \%$ for those treated with Dagin ( $\mathrm{U}=66.5, \mathrm{p}$ $<0.001)$ and $12.6 \pm 28.24 \%$ for those in control tanks $(\mathrm{U}=24.5, \mathrm{p}<0.001)$. There was no significant difference observed between those treated with Dagin and the control ( $p>0.05)$.

There were differences in mean hatchability among treatments (KruskalWallis $\left.\chi^{2}=8.46, \mathrm{df}=2, \mathrm{p}<0.001\right)$. Hatchability mean value for females treated with catfish pituitary was $54.06 \pm$ $34.30 \%$ and was not significantly different from the mean of 29.2. $\pm 37 \%$ for females treated with the Dagin $(\mathrm{p}<0.05)$. It was, however, significantly higher than $9.5 \pm$ $20 \%$ for females that had not received hormonal treatment $(\mathrm{U}=46.0, \mathrm{P}<0.05)$. The difference between hatchability means for Dagin treatments and the control treatments mean (no hormone) were not significant $(\mathrm{p}>0.05)$. The standard deviation SD was highly variable from the mean in all treatments (Table 2).

Table 2. Measured parameters of second generation $\boldsymbol{B}$. altianalis females induced under captivity

\begin{tabular}{llll}
\hline Parameters & Pituitary extracts & Dagin & Control \\
\hline $\begin{array}{l}\text { Ovulation rate (released eggs } \\
\text { on pressing belly) }\end{array}$ & $100 \%(15)$ & $93.3 \%(14 q)$ & $93.3 \%(14)$ \\
working fecund (no. eggs) & $2314.40 \pm 882.04^{\mathrm{a}}$. & $1207.37 \pm 1270.91^{\mathrm{b}}$ & $416.47 \pm 800.84^{\mathrm{b}}$ \\
Mean fertilisation (\%) & $80.27 \pm 39.57^{\mathrm{a}}$ & $40.8 \pm 50.05^{\mathrm{b}}$ & $12.6 \pm 28.24^{\mathrm{b}}$ \\
Mean hatchability (\%) & $54.06 \pm 34.3^{\mathrm{a}}$ & $29.2 \pm 37.05^{\mathrm{ab}}$ & $9.5 \pm 20.15^{\mathrm{b}}$ \\
\hline
\end{tabular}


There were differences in working fecundity (number of eggs) among all the treatments (Kruskal-Wallis $\chi^{2}=14.64$, df $=2, \mathrm{p}<0.01)$. The mean working fecundity was $2314.40 \pm 882.04$ for females treated with catfish pituitary, $1207.73 \pm 1270.91$ for females treated with Dagin, and $416.47 \pm 800.84$ for those in control treatment. Fecundity was significant between females treated with catfish pituitary extract and those treated with Dagin $(U=59.5, p<0.05)$. Similarly, significant differences were observed between the females treated with catfish pituitary extract and the control treatment $(\mathrm{U}=20.5, \mathrm{p}<0.001)$. No significant differences were observed between females treated with Dagin and the control treatment $(\mathrm{P}>0.05)$.

In experiment II, the mean fertilisation rates for females striped after $4 \mathrm{hrs}(86.67$ $\pm 12.12 \%$ ) was comparatively higher than that for females striped after $10 \mathrm{hrs}(81.77$ $\pm 15.08 \%$ ); but were not significantly different from each other $(p>0.05)$. However, significant difference in mean hatchability was observed between the females striped after $4 \mathrm{hrs}$ (100 degree hours) and those that were striped after 10 hrs (250 degree hours) (Kruskal-Wallis; $\chi^{2}=6.58$, df $\left.=1, \mathrm{p}<0.01\right)$. Hatchability was $72.67 \pm 16.90 \%$ for the females striped after $4 \mathrm{hrs}$ and $37.17 \pm 21.36 \%$ for those striped after $10 \mathrm{hrs}$.

\section{Discussion}

In domestication of fish in captivity seasonal breeding is not a factor of massive seed strategy for commercialization of fish species; hence a constant year round production must be facilitated. This is possible by artificially manipulating the hormones. Results from this study indicated that, the fertilization rates, the working fecundity and hatchability rates were notably high when catfish pituitary extract was used compared to Dagin in a priming dosage. Pituitary extracts have been effective in inducing spawning in many migratory fishes (Zaniboni-Filho and Weingartner, 2007) including Brycon orbignyanus (Felizardo et al., 2010), Astyanax bimaculatus (Felizardo et al., 2012) and also in carps (Drori et al., 1994; Yaron et al., 1984; Harvey and Carolsfeld, 1994). But advancement in production of hormonal analogues, suggests that the development and introduction of analogues with anti-dopamine agents has become much easier and easily facilitate spawning with a single dosage in some fish (Drori et al., 1994; Yaron et al., 2009). The performance with Dagin in this study was generally not as good as that for pituitary extracts (Table 2 ) probably because the hormone was insufficient or required more degree hours to mature. The dosage used was a standard prescription for carps as recorded on vials (Kibbutz Gan Shmuel Fish Breeding Centre, Israel; Drori et al., 1994), but it is probable that by the time of stripping it could not facilitate adequate ripening of eggs compared to the dosages used for catfish pituitary extracts. The effective dosages of hormones to facilitate ripening of mature females may vary with fish species (Marte, 1989). Hence, the effective levels of Dagin for this species could further be investigated. Nevertheless, it was apparently noted that a dosage of $0.014 \mathrm{~g} \mathrm{ml}^{-1}$ made in $5 \%$ saline solution and provided in two consecutive dosages separated by 6 hrs (250 degree hours including the $4 \mathrm{hrs}$ of resting) was effective in facilitating ovulation in $B$. altianalis. Hence, the use of catfish extracts is preferable given its low cost and availability in the region. 
The very high variation in fertilization and hatchability rates observed during induced spawning (Table 2) may be reflective of the varying levels of egg maturation in $B$. altianalis. Barbus altianalis is a batch spawner with eggs developing in batches one after the other (Rutaisire et al., 2015). In the event of induced spawning, the egg batches do not ripen at the same time. Whereas some eggs will be recruited to replace ovulated ones, if the ovulated eggs are held in the ovary for long, they will become over ripen and at the time of striping they may not be viable. A similar situation was reported in other batch spawners such as Scophthalmus maximus L (McEvoy, 1984), in Gadus morhua (Kjesbu, 1989) and Hippoglossus hippoglossus (Bromage et al., 1994). This is typical of batch spawners and poses a challenge in induced spawning because the deterioration of egg quality is much faster, especially with spawners in tropics (Bromage et al., 1994). In females where fertilisation was very low or even zero, the produced eggs had nuclei in the middle of the eggs (observed when acetic acid was applied to ascertain the position of the nucleus). This situation was, especially observed in fish which had very few eggs, indicating that by the time of stripping the eggs had not matured to the level of ovulation. This subsequently affected the hatchability. However, there were instances where in some females the fertilisation rates were high, yet the hatchability was very low. This was attributed to over ripening (Kjesbu, 1989; Kjorsvik et al., 1990; Bromage et al., 1994; Thorsen et al. 2003).

The use of acetic acid to clear the eggs for nucleus observation revealed that no nucleus was observed and the eggs disintegrated easily when touched. This confirmed that the eggs became overripe. Over ripening was largely observed in females that produced eggs upon application of very slight pressure on the abdomen prior to induced spawning. This suggested that such fish did not require prior hormonal application and in the subsequent spawning experiment (experiment II), those fish were not induced with hormones. One of the biggest challenges in induced spawning of B. altianalis is that the fish does not show clear signs of breeding characteristics or bulging belly as observed in other cultured cyprinids, such as the Chinese and Indian carps (Jhingran and Pullin, 1985). Hence, the only option is to use a catheter and or pressing the belly to identify mature females.

In experiment II, when the females with some ripe running eggs were subjected to varying incubation latency period, the best fertilisation and hatchability rates were produced with those stripped after $4 \mathrm{hrs}$ (100 degree hours), without inducing them to spawn. The egg viability reduced when the eggs were striped at $10 \mathrm{hrs}$ ( 250 degree hours). This also indicated deterioration of the egg quality, i.e. the eggs were slowly becoming overripe. At 100 degree hours, the eggs nuclei were observed to be clearly at the animal pole, hence the majority of the batch eggs were viable. Various experimental reports established a minimum period by which the broodfish can retain viable ovulated eggs in their ovary. In common carp Cyprinus carpio and Hypophthalmichthys nobilis, eggs were found to remain viable after ovulation for between 50-80 minutes and 30-45 minutes in Ctenopharyngodon idella (Rottman et al., 1991). In species such as Rainbow trout, Oncorhynchus mykiss, eggs remain viable much longer 
(approximately 7 days) after ovulation but, can be shorter at between 4-6 hrs in Atlantic halibut Hippoglossus hippoglossus (Bromage et al., 1994). The delay to strip and fertilise the ovulated eggs will trigger over ripening. It was clear in experimental study II, that by the time the running eggs in $B$. altianalis were observed at the beginning of the experiment they needed a shorter period of time to be stripped and fertilized before they became overripe. However, this study did not ascertain the actual period of egg viability after ovulation and further investigation is required to confirm the actual egg viability period. Nevertheless, this was a cheap strategy of breeding $B$. altianalis because no hormones were used in experiment II, but is limited to seasonality. It was observed that the majority of fish with such running eggs when pressed on the belly were largely present during the rainy season. Most probably, this seasonal phenomenon observed with seasonal spawners is not only influenced by presence of food availability alone (Lam, 1983; Bye, 1984; Bromage et al., 1994; Lowe-McConnell, 1997), but is imprinted and was still carried in the second generation of $B$. altianalis held in captivity. This phenomenon was also reported in some cultured species such as Atlantic cod Gadus morhua L. (Ottera et al., 2012). This became a challenge to all year round production concept of seed in captivity. However, farmers still have an opportunity to breed this fish with reduced costs during the rainy seasons (breeding season), but can as well use catfish pituitary extract to induce spawning whenever the fingerlings are required.

The successful induced spawning followed a process of bringing together males and females and feeding them in the same pond. This suggests a courtship behavior which facilitated maturation of gonads. The presence of males around females has been found to facilitate gonadal maturation and development in a number of cultured fish including the Indian carps (Nandeesha et al., 1990), the Chinese carps (Jhingran and Pullin, 1985), the African catfish Clarius gariepnus (Waal, 1974) and the Channel catfish Ictalurus punctatus (Tucker and Robinson, 1990).In Chinese carps however, such as Ctenopharyngodon idella, Hypophthalmichthys molitrix and Aristichthys nobilis, induced spawning may be successful without courtship or pairing the males and females (Woynarovich and Horvath, 1980). In Cyprinus carpio, courtship was observed when a priming dosage of pituitary extract was provided, hence facilitating ovulation (Drori et al., 1994). However, no young ones were physically observed in the ponds indicating that the pond is not a suitable area for $B$. altianalis spawning.

This study has confirmed that the males with running milt are readily available whenever they are needed and this is never a constraint in induced spawning of $B$. altianalis. Their hormonal dosaging is irrelevant provided they are brought together with female prior to spawning. The technique of raising the fish together as observed in this study was found to be a pre-requisite to spawning $B$. altianalis and must be included in spawning protocol for use by prospective farmers or hatchery producers.

\section{Conclusion}

This study has ascertained that the use of catfish pituitary extracts $\left(0.014 \mathrm{~g} \mathrm{ml}^{-1}\right.$ made in 5\% saline solution) administered in a two consecutive dosages (priming and 
resolving) is an effective and a cheaper option in inducing $B$. altianalis to spawn. However, more costs are reduced when ripe running females are only facilitated to release eggs without any hormonal application for a latency period of 100 degree hours using only flashing (running) water, especially during the rainy season. Prior to spawning, it is inevitable to bring the fish together in order to facilitate maturation and ripening of both eggs and sperms. The study has also registered successful completion of the breeding cycle in captivity, a good strategy to guarantee continued production of seed and selection for better broodstocks. It is recommended that an investigation shouhd be conducted to ascertain the actual period of egg viability after ovulation. Despite the high cost of using Dagin, it may still be necessary to determine the appropriate dosage of Dagin for induced spawning in $B$. altianalis because the prescribed standard for carps used in this study did not perform well.

\section{Acknowledgment}

We acknowledge financial support from the Agriculture Technology Development and Advisory Services project (ATAAS), funded by Government of Uganda through a facility by the World Bank managed locally by the National Agriculture Research Organization (NARO). We are grateful to Ssenya fish Farm for allowing us to conduct the study on their farm in Lwengo district. We thank Kimera Bridget the project technician for her effort in feeding and participating in sampling activities at the Farm.

\section{References}

Afzal, M.R.A., Akhtar, N. Ahmed, I.F., Khan, M. and Qayyum, M. 2008. Growth performance of bighead carp Aristichthys nobilis (Richardson) in monoculture system with and without supplementary feeding. Pakistan Veterinary Journal 28(2): 57-62.

Bromage, N. 1998. Broodstock management and the optimisation of seed supplies. Aquaculture Science 46(3): 395-401.

Bromage, N., Bruce, M., Basavaraja, N., Rana, K., Shields, R., Young, C. and Gamble, J. 1994. Egg quality determinants in finfish the role of overripening with special reference to the timing of stripping in the Atlantic halibut Hippoglossus hippoglossus. Journal of the World Aquaculture Society 25(1): 13-21.

Bye, V. J. 1984. The role of environmental factors in the timing of reproductive cycles. Fish Reproduction: Strategies and Tactics 187-205.

Chaudhuri, H. 1976. Use of hormones in induced spawning carps. Journal of the Fisheries Research Board of Canada 33: 940-7.

de Graaf, G. and Janssen, H. 1996. Artificial reproduction and pond rearing of the African catfish Clarius gariepinus in subsahara Africa A Hand Book: FAO Fisheries Technical Paper No. 362. pp. 1-73. FAO, Rome, Italy.

Drori, S., Ofir, M., Levavi-Sivan, B. and Yaron, Z. 1994. Spawning induction in common carp (Cyprinus carpio) using pituitary extract or GnRH superactive analogue combined with 
metoclopramide: analysis of hormone profile, progress of oocyte maturation and dependence on temperature. Aquaculture 119(4): 393-407.

Felizardo, V.D.O., Murgas, L.D.S., Drumond, M.M. and Silva, J.D.A. 2010. Insemination dose used in the artificial fertilization of piracanjuba ovocyte (Brycon orbignyanus). Revista Ceres 57(5): 648-652.

Felizardo, V.O., Murgas, L.D.S., Andrade, E.S., Lopez, P. A., Freitas, R. T. F. and Ferreira, M. R. 2012. Effect of timing of hormonal induction on reproductive activity in lambari (h). Theriogenology 77(8): 1570-1574.

Funge-Smith, S., Phillips, M.J. 2001. Aquaculture systems and species. In: R.P. Subasinghe, P. Bueno, M.J. Phillips, C. Hough, S.E. McGladdery and J.R. Arthur (Eds.), Technical Proceedings of the Conference on Aquaculture in the Third Millennium. pp. 129-135. Bangkok, Thailand, February 20-25, 2000. NACA/FAO, Bangkok/ Rome, Italy.

Harvey, B. and Carolsfeld, J. 1993. Induced Breeding in Tropical Fish Culture. IDRC, Ottawa. 145 pp.

Indira, T., Damodaran. R. and Priyadarshini, R., 2013. Comparative study of synthetic hormones ovaprim and carp pituitary extract used in induced breeding in Indian major carp. Supplement to Advanced Bio Technology 12(07): 49-52.

Jhingran, V.G. and Pullin, R.S.V. 1985. A hatchery manual for the common, Chinese and Indian major carps. Asian Development Bank and International Center for Living Aquatic Resources Management (ICLARM) Studies and Reviews 11: $1-191$.
Kjesbu, O. S. 1989. The spawning activity of cod, Gadus morhua L. Journal of Fish Biology 34(2): 195-206.

Kjorsvik, E., Mangor-Jensen, A. and Holmefjord, I. 1990. Egg quality in fishes. Advances in Marine Biology 26: 71-113.

Lam, T. J. 1983. Environmental Influences on Gonadal Activity in Fish. Fish Physiology 9: 65-116.

Levavi-Sivan B., Bogerd, J., Mananos, E.L., Gomez, A. and Lareyre, J.J., 2010. Perspectives on fish gonadotropins and their receptors. General and Comparative Endocrinology 165: 412-437.

Lowe-McConnell, R.H. 1979. Ecological aspects of seasonality in fishes of tropical waters. In Symposia of the Zoological Society of London 44: 219-241).

Mahfuj, M.S., Hossein, M.A. and Sarower, M.G. 2012. Effect of different feeds on larvae development and survival of ornamental Coi carp, Cyprinus carpio larvae in laboratory condition. Journal of Bangladesh Agricultural University 10 (1): 179183.

Marte, C.L. 1989. Hormonal -induced spawning of cultured tropical fin fishes. Advances in Tropical Aquaculture 9:519-539.

Mwanja, M., Rutaisire, J., Ondhoro, C., Ddungu, R. and Aruho, C. 2015. Current fish hatchery practices in Uganda: The potential for future investment. International Journal of Fisheries and Aquatic Studies 2(4): 224-232.

McEvoy, L.A. 1984. Ovulatory rhythms and over-ripening of eggs in cultivated turbot, Scophthalmus maximus L. 
Journal of Fish Biology 24(4): 437448.

Miah, M.I., Mamun, A.A., Khan. M. M.R. and Rahman. M.M. 2008. Dose optimization with pituitary gland hormone for induced breeding of Bata fish (Labeo bata). Bangladesh Journal of Animal Sciences 37 (1): $70-77$.

Munro, A.D. 1990. General introduction. In: A.D. Munro, A.P. Scott and T.J. Lam (Eds.), Reproductive seasonality in teleosts: environmental influences. pp. 1-11. Boca Raton, Florida, USA, CRC Press.

Nagahama Y. 1994. Endocrine regulation of gametogenesis in fish. International Journal of Developmental Biology 38(2): 217-29.

Nandeesha, M.C., Rao, K.G., Jayanna, R., Parker, N.C., Varghese, T.J., Keshavanath, P. and Shetty, H.P. 1990. Induced spawning of Indian major carps through single application of Ovaprim-C. In: R. Hirano and I. Hanvu (Eds.). The Second Asian Fisheries Forum. pp. 581-585. Asian Fisheries Society, Manila, Philippines.

Ottera, H., Agnalt, A.L., Thorsen, A., Kjesbu, O.S., Dahle, G. and Jorstad, K. 2012. Is spawning time of marine fish imprinted in the genes? A twogeneration experiment on local Atlantic cod (Gadus morhua L.) populations from different geographical regions. ICES Journal of Marine Science: Journal du Conseil fss, 135.

Peter, R.E. and Yu, K.L. 1997. Neuralendocrine regulation of ovulation in fishes. Basic and applied aspects. Revisions in Fish Biology and Fisheries 7: 173-197.

Poulsen., A.F. and Valbo-Jørgensen, J. 2000. Fish migrations and spawning habits in the Mekong mainstream - A survey using local knowledge. Assessment of Mekong Fisheries: Fish Migrations and Spawning and the Impact of Water Management Project (AMFC) Vientiane, Lao P.D.R. February 2000. 132 pp.

Rottman, R.W., Shireman, J.V. and Chapman, F.A. 1991. Techniques for taking and fertilizing the spawn of fish, Publication No. 426. Stoneville, Mississippi: Southern Regional Aquaculture Center (SRAC).

Rutaisire, J., Levavi Sivan, B., Aruho, C. and Ondhoro, C.C. 2015. Gonadal recrudescence and induced spawning in Barbus altianalis. Aquaculture Research 46(3): 669-678. DOI: 10.1111/are.12213

Stickney, R.R. 2005. Aquaculture: An introductory text, CABI Publ, Cambridge, USA. 256pp.

Tucker, C.C. and Robinson, E.H. 1990. Channel catfish farming handbook. Springer Science \& Business Media.

Thorsen, A., Trippel, E.A. and Lambert, Y. 2003. Experimental methods to monitor the production and quality of eggs of captive marine fish. Journal of Northwest Atlantic Fishery Science 33: 55-70.

Waal, B.C.W. 1974. Observations on the breeding habits of Clarias gariepinus (Burchell). Journal of Fish Biology 6(1): 23-27.

Weltzien, F.A., Norberg, B. and Swanson, P. 2003. Isolation and characterization of FSH and LH from pituitary glands of Atlantic halibut (Hippoglossus hippoglossus L.). General and Comparative Endocrinology 131 (2): 97-10.

Woynarovich, E. and Horva, L. 1980. The artificial propagation of warm-water finfishes - a manual for extension, 
FAO Fisheries Techenical Paper 201. Zaniboni-Filho, E. and Weingartner, M. pp.1- 183. FAO, Rome Italy.

Yaron, Z., Bogomolnaya, A. and Levavi, B. 1984. A calibrated carp pituitary extract as a spawning-inducing agent. Research on Aquaculture 8: 151-168. Yaron Z., Bogomoinaya, A., Drori, S., Biton, I., Aizen, J., Kulikovsky, Z. and Levavi-Sivan, B. 2009. Spawning induction in the carp: past experience and future prospects-a review. Israel Journal of Aquaculture. Bamidgeh 61(1): 5-26. 2007. Induced breeding in migratory fishes. Revista brasileira De reproducao Animal Belo Horizant 31(3): 367-373.

Zohar, Y. and Mylonas, C.C. 2001. Endocrine manipulations of spawning in cultured fish: from hormones to genes. Aquaculture 197(1): 99-136.

Zohar, Y., Munoz-Cueto, J.A., Elizur, A. and Kah, O. 2010. Neuroendocrinology of reproduction in teleost fish. General and Comparative Endocrinology 165: 438-455. 